Japan. J. Med. Sci. Biol., 29, 187-197, 1976

\title{
FAILURE TO PROVE ARENAVIRUS INFECTION AMONG THE SMALL MAMMALS FROM AN ENDEMIC AREA OF KOREAN HEMORRHAGIC NEPHROSONEPHRITIS
}

\section{Takeshi OKUNO*, Jordi CASALS**, Kyong-Ho KIM***, Dan W. WALTON*, Hak-kin SHIN*** and Eui-bum JEONG***}

*Vector Ecology and Control Research Unit/World Health Organization, Seoul, Republic of Korea, **Yale Arbovirus Research Unit, Department of Epidemiology and Public Health, Yale University School of Medicine, New Haven, Connecticut 06510, USA and ***Department of Virology, National Institute of Health, Seoul, Republic of Korea

(Received: April 27, 1976)

\begin{abstract}
SUMMARY : In the light of recent knowledge on a complex of diseases caused by a new group of viruses, arenaviruses, virological studies largely directed toward small field mammals were undertaken during 1973-1974 aiming at etiological clarification of Korean hemorrhagic nephrosonephritis (KHNN). Specimens were collected in an endemic area of KHNN located north to northeast of Seoul. Virus isolation tests with 299 urine specimens and 131 mite pools recovered from small mammals and 14 acute stage sera from typical cases yielded negative results. Complement-fixation (CF) tests failed to detect antibodies against the antigens of Congo, lymphocytic choriomeningitis (LCM), Tacaribe, and Pichinde viruses among 366 small mammal sera. In addition, CF tests of 59 of the above sera against Apoi and Lassa virus antigens were negative. The results do not support the likelihood of an arenavirus being transmitted among Korean small field mammals, the overwhelming majority of which were Apodemus agrarius. A hypothesis that KHNN is caused by a virus of small field mammal origin was not proved within the technical limit of relatively unsophisticated methods employed herein.
\end{abstract}

\section{INTRODUCTION}

Despite the continuous study for the 3 decades since the disease was first described in 1942 (Ishii, 1942), the etiology of Korean hemorrhagic nephrosonephritis (KHNN) remains unknown. The clinical symptoms of the disease resemble those caused by an acute systemic infection. The failure of common antibiotics to alter the clinical course of the disease reduces the possibility of a bacterial, rickettsial, chlamidial or leptospiral etiology. Attempts to isolate a virus from patients, rodents and ectoparasites found in the endemic area of KHNN by conventional methods have so far been unsuccessful.

The isolation of Junin, Machupo and Lassa viruses, causative agents of

* Request for offprints should be addressed to: Ecology and Control of Vectors Unit, Division of Vector Biology and Control, WHO Headquarters, Geneva, Switzerland. 
Argentinian hemorrhagic fever (Parodi et al., 1958), Bolivian hemorrhagic fever (Johnson et al., 1965), and Lassa fever (Buckley and Casals, 1970), respectively, together with knowledge gained in ecological and virological surveys of small mammals have led us to the recognition of a new group of viruses, the arenaviruses. Gurrently-known distribution of the arenaviruses extends to both Americas (lymphocytic choriomenigitis (LCM), Junin, Machupo, Tacaribe, Pichinde, Amapari, Parana and Latino viruses), Europe (LCM virus) and Africa (Lassa virus), but not Asia. The reservoir role of small mammals in the natural transmission cycle of arenaviruses have been either well established or presumed with suggestive evidence. In the majority of the arenaviruses, virus transmission among reservoir mammals is known to take place (a) horizontally, via excreta, and (b) vertically, through the mechanism of immunological tolerance.

During 1973-1974 an ecological survey of small field mammals was made by the Vector Ecology and Control Research Unit (VECRU)/WHO in the socalled "classical" endemic area of KHNN (Walton and Hong, unpublished data). It was an important objective of the survey to examine the possibility of arenavirus infection among a number of common genera of small mammals found in the endemic area. The present paper describes the results of the virus isolation and serological tests performed on the urine and sera of Korean small mammals, respectively. The results of additional tests made for virus in a small number of patients' sera and mite pools are also presented.

\section{Materials AND Methods}

The study area (Fig. 1): The "classical" endemic area of KHNN stretches over two northern provinces of the Republic of Korea, namely, Gyeonggi-Do and Gangweon-Do being bordered on the southwest by the Seoul Municipality. The area is about $100 \mathrm{~km}$ long (west-east) and $30-70 \mathrm{~km}$ wide (north-south). Its border on the west consists of a plain along the lower stream of Han River. Hills, valleys and isolated mountains give a rather complicated topography to the western three-fifths of the endemic area. The eastern two-fifths consist of mountainous areas.

Rice paddies are common in the valleys among mountains as well as in the plain. Irrigation systems are generally poor. Domiciles and hamlets are situated alongside valleys and on the slopes of low hills. Isolated deciduous forests and shrubs are common.

Epidemiological data on KHNN for the whole of the country are available in a recent publication (Kim, Antal and Shin, 1974). Tables I and II show geographical and seasonal breakdown of KHNN cases which occurred during 1972-1974 in the classical endemic area.

Specimen collection from small mammals: Detailed account of the small 


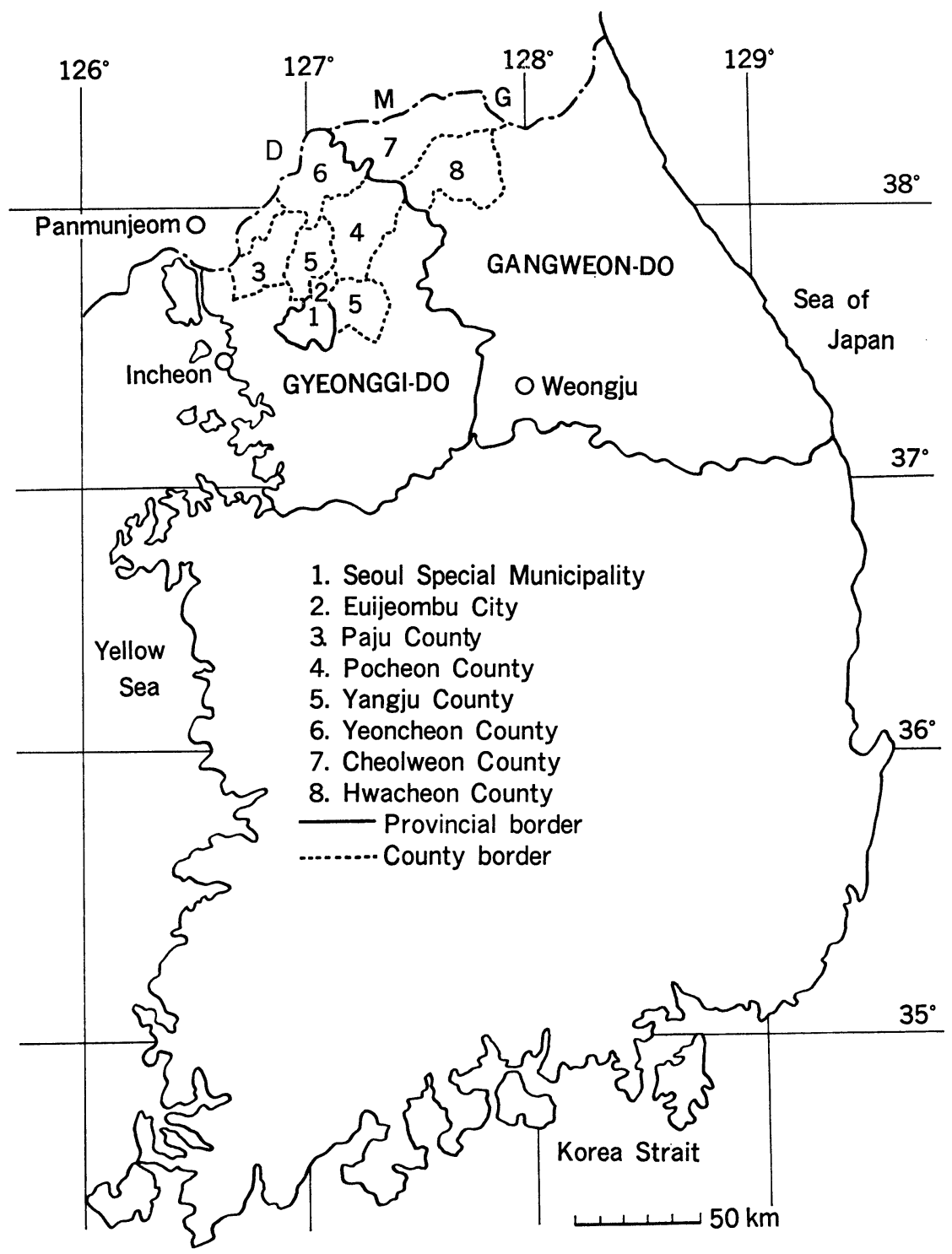

Fig. 1. Geographical location of the study area.

mammal collection is described elsewhere (Walton and Hong, unpublished data). Shortly after the arrival at the laboratory, each animal was anaesthesized with chloroform in a vinyl bag, examined for ectoparasites, and pinned down on a cork board covered with aluminum foil. Animals were exsanguinated by cardiac puncture. Urine leaked out during the above operation or passed by the animal upon removal from the trap was collected with a sterile capillary pipette into 
TABLE I

Number of reported cases and deaths of Korean hemorrhagic neprosonephritis, and morbidity rate in the Seoul Special Municipality, Gyeonggi and Cangweon Provinces

\begin{tabular}{|c|c|c|c|c|c|c|c|c|c|c|}
\hline \multirow{3}{*}{$\begin{array}{l}\text { City, Province, } \\
\text { Town \& County }\end{array}$} & \multirow{3}{*}{ Population* } & \multicolumn{6}{|c|}{$\begin{array}{l}\text { Number of cases and } \\
\text { deaths each year }\end{array}$} & \multicolumn{3}{|c|}{$\begin{array}{l}\text { Morbidity rate per } \\
\text { population of } 100000\end{array}$} \\
\hline & & \multicolumn{2}{|c|}{1972} & \multicolumn{2}{|c|}{1973} & \multicolumn{2}{|c|}{1974} & \multirow{2}{*}{1972} & \multirow{2}{*}{1973} & \multirow{2}{*}{1974} \\
\hline & & $\mathrm{C}$ & $\mathrm{D}$ & $\mathbf{C}$ & D & C & D & & & \\
\hline Seoul & $5 \quad 536 \quad 377$ & 7 & 0 & 5 & 0 & 2 & 0 & 0.13 & 0.09 & 0.04 \\
\hline Gyeonggi-Do & $\begin{array}{lll}3 & 358 & 105\end{array}$ & 85 & 4 & 53 & 4 & 55 & 3 & 2.53 & 1.58 & 1.64 \\
\hline Bucheon & $147 \quad 523$ & 1 & 0 & 0 & 0 & 0 & 0 & 0.68 & - & - \\
\hline Euijeombu & 94348 & 3 & 1 & 5 & 0 & 0 & 0 & 3.18 & 5.30 & - \\
\hline Gapyeong & 69771 & 1 & 0 & 1 & 0 & 0 & 0 & 1.43 & 1.43 & - \\
\hline Gimpo & $\begin{array}{ll}78 & 071\end{array}$ & 2 & 0 & 0 & 0 & 1 & 0 & 2.56 & - & 1.28 \\
\hline Goyang & 133253 & 0 & 0 & 0 & 0 & 2 & 0 & - & - & 1.50 \\
\hline Gwangju & 140735 & 1 & 0 & 0 & 0 & 0 & 0 & 0.71 & - & - \\
\hline Icheon & 106147 & 0 & 0 & 1 & 1 & 0 & 0 & - & 0.94 & - \\
\hline Incheon & 646013 & 1 & 0 & 0 & 0 & 0 & 0 & 0.15 & - & - \\
\hline Paju & 191303 & 17 & 0 & 31 & 3 & 41 & 3 & 8.89 & 16.20 & 21.43 \\
\hline Pocheon & 126999 & 25 & 1 & 6 & 0 & 5 & 0 & 19.69 & 4.72 & 3.94 \\
\hline Siheung & 186503 & 2 & 0 & 0 & 0 & 0 & 0 & 1.07 & - & - \\
\hline Yangju & 248696 & 9 & 0 & 3 & 0 & 1 & 0 & 3.62 & 1.21 & 0.40 \\
\hline Yangpyeong & 106118 & 0 & 0 & 1 & 0 & 0 & 0 & - & 0.94 & - \\
\hline Yeoju & 101023 & 1 & 0 & 1 & 0 & 0 & 0 & 0.99 & 0.99 & - \\
\hline Yeoncheon & $\begin{array}{lll}60 & 071\end{array}$ & 22 & 2 & 4 & 0 & 3 & 0 & 36.62 & 6.66 & 4.99 \\
\hline Yongin & 96538 & 0 & 0 & 0 & 0 & 2 & 0 & - & - & 2.07 \\
\hline Other area & 824993 & 0 & 0 & 0 & 0 & 0 & 0 & - & - & - \\
\hline Gangweon-Do & 1866928 & 30 & 2 & 38 & 2 & 49 & 5 & 1.61 & 2.04 & 2.62 \\
\hline Cheolweon & 59689 & 7 & 1 & 1 & 0 & 1 & 0 & 11.73 & 1.68 & 1.68 \\
\hline Chuncheon & 122485 & 0 & 0 & 0 & 0 & 2 & 0 & - & - & 1.63 \\
\hline Chunseong & $\begin{array}{ll}87 & 126\end{array}$ & 0 & 0 & 1 & 0 & 0 & 0 & - & 1.15 & - \\
\hline Gangneung & 74352 & 1 & 0 & 0 & 0 & 0 & 0 & 1.34 & - & - \\
\hline Hongcheon & 123892 & 2 & 0 & 1 & 0 & 7 & 1 & 1.61 & 0.81 & 5.65 \\
\hline Hwacheon & 50689 & 4 & 0 & 0 & 0 & 2 & 0 & 7.89 & - & 3.95 \\
\hline Hwoingseong & 94152 & 0 & 0 & 6 & 1 & 11 & 1 & - & 6.37 & 11.68 \\
\hline Inje & 61553 & 1 & 0 & 0 & 0 & 5 & 1 & 1.62 & - & 8.12 \\
\hline Jeong-seong & 113448 & 2 & 1 & 0 & 0 & 1 & 0 & 1.76 & - & 0.88 \\
\hline Myeongju & 65015 & 1 & 0 & 0 & 0 & 0 & 0 & 1.54 & - & - \\
\hline Pyeongchang & 96941 & 0 & 0 & 3 & 0 & 0 & 0 & - & 3.09 & - \\
\hline Samcheog & 277041 & 0 & 0 & 2 & 0 & 1 & 0 & - & 0.72 & 0.36 \\
\hline Sogcho & $\begin{array}{ll}73 & 058\end{array}$ & 1 & 0 & 0 & 0 & 0 & 0 & 1.37 & - & - \\
\hline Weonju & 111855 & 8 & 0 & 9 & 1 & 7 & 0 & 7.15 & 8.05 & 6.26 \\
\hline Weongseong & 90479 & 2 & 0 & 13 & 0 & 5 & 1 & 2.21 & 14.37 & 5.53 \\
\hline Yang-gu & 38919 & 1 & 0 & 0 & 0 & 3 & 0 & 2.57 & - & 7.71 \\
\hline Yeongweol & 123668 & 0 & 0 & 2 & 0 & 4 & 1 & - & 1.62 & 3.23 \\
\hline Other area & 202566 & 0 & 0 & 0 & 0 & 0 & 0 & - & - & - \\
\hline Total & 10761410 & 122 & 6 & 96 & 6 & 106 & 8 & 1.13 & 0.89 & 0.99 \\
\hline
\end{tabular}

* Source: Yearbook of Public Health and Social Statistics (1971) by the Ministry of Health and Social Affairs, Republic of Korea 
TABLE II

Monthly occurrence of KHNN cases in four counties where most of the specimens were collected for virological testing

\begin{tabular}{|c|c|c|c|c|c|c|c|c|c|c|c|c|c|c|}
\hline \multirow{2}{*}{ Year } & \multirow{2}{*}{ County } & \multicolumn{13}{|c|}{ Number of cases per month } \\
\hline & & Jan & Feb & Mar & Apr & May & Jun & Jul & Aug & Sep & Oct & Nov & Dec & Total \\
\hline \multirow{4}{*}{$\begin{array}{l}\mathcal{N} \\
\text { S. }\end{array}$} & Paju & & & & & & & & & 2 & 6 & 9 & & 17 \\
\hline & Pocheon & & & & & & & & & 1 & 5 & 14 & 5 & 25 \\
\hline & Yangju & & & & & & & & & 1 & 2 & 6 & & 9 \\
\hline & Yeoncheon & 1 & 2 & 1 & & & 1 & 2 & & & 1 & 9 & 5 & 22 \\
\hline \multirow{4}{*}{$\begin{array}{l}\text { 号 } \\
\text { }\end{array}$} & Paju & 2 & & 1 & & & & & & 1 & 13 & 13 & & 21 \\
\hline & Pocheon & & & & & & & & 2 & 3 & 1 & & & 6 \\
\hline & Yangju & & & & & & & & 1 & & & 1 & & 4 \\
\hline & Yeoncheon & 3 & & & & & & & & & & & 1 & 4 \\
\hline \multirow{4}{*}{ 芯 } & Paju & & & & & 2 & & & 1 & 2 & 13 & 17 & 6 & 41 \\
\hline & Pocheon & & & & & & & & & 1 & 1 & & 3 & 5 \\
\hline & Yangju & & & & & & & & & & & & 1 & 1 \\
\hline & Yeoncheon & & & & & & & & & & & & 3 & 3 \\
\hline
\end{tabular}

a screw-capped vial. Roughly an equal volume of a diluent* was added prior to storage at $-60 \mathrm{C}$. The 1:2 dilution was necessary to prevent the immediate death of inoculated mice due to the toxicity of the urine. The sera were separated on the following day and stored at $-60 \mathrm{C}$.

Preparation of mite-pool suspension: Mites were pooled into various sizes by individual animal immediately after bleeding. Pools of mites stored frozen at $-60 \mathrm{C}$ were ground in a mortar with $1.5 \mathrm{ml}$ of the diluent shortly before inoculation. The inocula were the supernatants following light centrifugation $(2,500 \mathrm{rpm}, 15 \mathrm{~min})$ at temperature not exceeding $10 \mathrm{C}$.

Specimen collection from patients: Blood specimens from patients were hand-carried to the laboratory in ice-bath. After separation sera were stored at $-60 \mathrm{C}$ until inoculation.

Virus isolation tests: Tests on small mammal urine and the patients' sera were carried out exclusively at the VECRU laboratory located in the National Institute of Health (NIH), Seoul. Mite pools were processed at both VECRU and Yale Arbovirus Research Unit (YARU), New Haven to which the specimens were forwarded by air with dry ice.

During the study period, the intracerebral inoculation of suckling mice (2 to 4-day-old, from a colony at NIH/Seoul or YARU/New Haven) was the sole method employed for virus isolation. Inoculated mice were observed for 3 weeks. Two to three blind passages were made for patient's sera on every 7 th day after inoculation. Otherwise, subpassages were performed only for suspected mice.

* $0.75 \%$ bovine plasma albumin in phosphate-buffered saline containing 200 units of penicillin and $200 \mu \mathrm{g}$ of streptomycin. 
Bacteriological sterility was checked in all subpassages in thioglycolate media.

Serological tests: Both hemagglutination-inhibition (HI) and complementfixation (CF) tests were carried out at YARU by one of the authors (J.C.). Both tests were performed by the microtiter system.

a) In the $\mathrm{HI}$ tests, the sera were treated with kaolin and 8 units of the following arbovirus antigens were used:

Group A: chikungunya, Getah, Sindbis, eastern equine encephalitis

Group B: dengu type 2, Japanese encephalitis (JE), Murray Valley encephalitis, Russian spring-summer encephalitis, Zika, Wesselsbron, Tembusu, Royal Farm, yellow fever

Bakau group: Ketapang

b) In the CF tests, the sera were tested in dilution 1:4, 1:8 and 1:16. Eight or 16 units of antigens of the following viruses were employed:

arbovirus group B: dengue type 2, Apoi

arbovirus group Congo: Congo (strain UG 3010)

Arenavirus: LGM (strain Bulgaria).

Tacaribe (strain TR 11573),

Pichinde (strain Co An 3739),

Lassa

mousepoliovirus: ASK-1

Appropriate controls for serum anticomplementary activity and antigen potency were used in each performance of the CF tests.

\section{Results}

\section{Virus Isolation from the Urine Specimens Collected from Small Mammals}

No virus was isolated from 299 urine specimens despite subpassages performed for 21 specimens which yielded apparently sick mice in the initial inoculation. Tables III and IV present the breakdown of 299 specimens by small mammal genus, and the place and month of their collection. It is noted in Table III that the urine of nearly 300 small mammals trapped during the two epidemic seasons were inoculated. Apodemus agrarius (251 individuals) comprised the overwhelming majority among the 299 tested. The largest number of specimens were from Pocheon County (115 individuals) followed by those from Paju County (103 individuals) as shown in Table IV.

\section{Virus Isolation from Mite Pools Recovered from Small Mammals}

A total of 131 mite pools were tested for virus. Fifty-five of the above pools were recovered from mammal trapped between 16 October-29 November, 1973, 
TABLE III

Number of urine specimens inoculated into suckling mice by the genus of small mammals and month of collection

\begin{tabular}{|c|c|c|c|c|c|c|c|c|c|c|c|c|c|}
\hline \multirow{2}{*}{ Genus } & \multicolumn{6}{|c|}{1973} & \multicolumn{6}{|c|}{1974} & \multirow[b]{2}{*}{ Total } \\
\hline & July & Aug & Sept & Oct & Nov & Dec & Jan & Feb & Mar & Apr & May & June & \\
\hline Apodemus & 7 & 10 & 5 & 21 & 85 & 10 & 2 & 8 & 6 & 43 & 26 & 28 & 251 \\
\hline Microtus & 0 & 0 & 0 & 0 & 4 & 2 & 0 & 3 & 4 & 1 & 4 & 0 & 18 \\
\hline Eothenomys & 0 & 0 & 0 & 0 & 1 & 0 & 0 & 3 & 1 & 2 & 6 & 4 & 17 \\
\hline Rattus & 0 & 0 & 0 & 0 & 0 & 0 & 1 & 0 & 0 & 0 & 0 & 0 & 1 \\
\hline Mus & 0 & 0 & 0 & 0 & 0 & 2 & 0 & 0 & 0 & 0 & 0 & 3 & 5 \\
\hline Micromys & 0 & 0 & 0 & 0 & 0 & 1 & 0 & 0 & 0 & 0 & 0 & 0 & 1 \\
\hline Crocidura & 0 & 0 & 0 & 1 & 2 & 0 & 0 & 0 & 0 & 0 & 3 & 0 & 6 \\
\hline Total & 7 & 10 & 5 & 22 & 92 & 15 & 3 & 14 & 11 & 46 & 39 & 35 & 299 \\
\hline
\end{tabular}

TABLE IV

Number of urine specimens inoculated into suckling mice by the month and the place of collection of small mammals

\begin{tabular}{|c|c|c|c|c|c|c|c|c|c|c|c|c|c|}
\hline \multirow{2}{*}{$\begin{array}{l}\text { County or } \\
\text { City }\end{array}$} & \multicolumn{6}{|c|}{1973} & \multicolumn{6}{|c|}{1974} & \multirow[b]{2}{*}{ Total } \\
\hline & July & Aug & Sept & Oct & Nov & Dec & Jan & Feb & Mar & Apr & May & June & \\
\hline Cheolweon & 0 & 0 & 0 & 0 & 0 & 0 & 0 & 0 & 0 & 0 & 12 & 0 & 12 \\
\hline Yeoncheon & 0 & 0 & 0 & 2 & 16 & 0 & 0 & 0 & 0 & 0 & 0 & 8 & 26 \\
\hline Pocheon & 5 & 7 & 5 & 2 & 30 & 13 & 1 & 4 & 9 & 14 & 12 & 13 & 115 \\
\hline Yangju & 0 & 0 & 0 & 0 & 13 & 0 & 0 & 4 & 0 & 10 & 7 & 3 & 37 \\
\hline Paju & 2 & 3 & 0 & 18 & 33 & 2 & 1 & 6 & 2 & 22 & 5 & 9 & 103 \\
\hline Seoul & 0 & 0 & 0 & 0 & 0 & 0 & 0 & 0 & 0 & 0 & 3 & 2 & 5 \\
\hline Weonju & 0 & 0 & 0 & 0 & 0 & 0 & 1 & 0 & 0 & 0 & 0 & 0 & 1 \\
\hline Total & 7 & 10 & 5 & 22 & 92 & 15 & 3 & 14 & 11 & 46 & 39 & 25 & 299 \\
\hline
\end{tabular}

and the remainder were pooled in 1974. Breakdown by mammal species indicates that 110 pools were from Apodemus agrarius, 13 from Microtus fortis, and 8 from Eothenomys regulus. Fifty-one of 131 pools were from Paju County. No agents pathogenic to mice were isolated.

\section{Virus Isolation from Patients' Sera}

Table V summarizes a brief history of each KHNN case the serum of which was tested for etiological agents. Eight of the 14 sera were collected within the initial 5 days of illness. Seven cases were from Paju County. Despite the blind passages no virus was recovered.

\section{Testing for Viral Antibodies in Small Mammal Sera}

a) HI antibodies: Fifty randomly selected sera from small mammals were tested. Two sera from Apodemus agrarius trapped in September and October, 
TABLE V

List of KHNN cases for which virus isolation from serum was attempted

\begin{tabular}{|c|c|c|c|c|c|c|c|c|c|c|}
\hline \multirow{2}{*}{$\begin{array}{l}\text { Serial } \\
\text { No. }\end{array}$} & \multirow{2}{*}{ Sex } & \multirow{2}{*}{ Age } & \multirow{2}{*}{$\begin{array}{c}\text { Occupa- } \\
\text { tion }\end{array}$} & \multirow{2}{*}{$\begin{array}{c}\text { Home } \\
\text { address } \\
\text { (County) }\end{array}$} & \multirow{2}{*}{$\begin{array}{c}\text { Onset } \\
\text { date }\end{array}$} & \multicolumn{3}{|c|}{ Clinical intensity } & \multirow{2}{*}{$\begin{array}{l}\text { Day of } \\
\text { illness } \\
\text { when } \\
\text { bled }\end{array}$} & \multirow{2}{*}{$\begin{array}{l}\text { Number } \\
\text { of pas- } \\
\text { sages in } \\
\text { suckling } \\
\text { mice }\end{array}$} \\
\hline & & & & & & Fever & $\begin{array}{l}\text { Haemor- } \\
\text { rhage }\end{array}$ & $\begin{array}{l}\text { Protein- } \\
\text { uria }\end{array}$ & & \\
\hline H-172 & $\mathbf{M}$ & 17 & farmer & Paju & $22 /$ Oct $/ 72$ & + & - & $H$ & 6 & 3 \\
\hline $\mathrm{H}-272$ & $\mathbf{F}$ & 40 & housewife & Paju & $18 /$ Oct $/ 72$ & $?$ & - & $H$ & 10 & 3 \\
\hline H-372 & $\mathbf{F}$ & 52 & housewife & Paju & $24 /$ Oct $/ 72$ & + & + & $H$ & 4 & 3 \\
\hline H-472 & $\mathbf{M}$ & 29 & teacher & Pocheon & 17/Dec/72 & H & - & H & 3 & 8 \\
\hline H-173 & $\mathbf{M}$ & 41 & farmer & Paju & $18 / \mathrm{Jan} / 73$ & + & + & H & 5 & 2 \\
\hline H-273 & $\mathbf{M}$ & 29 & farmer & Paju & 27/Jan/73 & + & + & + & 8 & 2 \\
\hline H-373 & $\mathbf{M}$ & 40 & laborer & Paju & 8/Mar/73 & + & + & \# & 6 & 2 \\
\hline H-473 & $\mathbf{M}$ & 28 & $\begin{array}{l}\text { government } \\
\text { employee }\end{array}$ & Paju & 29/Apr/73 & + & + & W & 4 & 3 \\
\hline H-573 & $\mathbf{M}$ & 31 & merchant & Yangju & 17/Jun/73 & + & $?$ & 世 & 5 & 2 \\
\hline H-673 & $\mathbf{M}$ & 51 & farmer & Pocheon & 24/Aug/73 & $H$ & $H$ & H & 4 & 3 \\
\hline $\mathrm{H}-773$ & $\mathbf{M}$ & 26 & farmer & Pocheon & $5 / \mathrm{Sep} / 73$ & \pm & + & $H$ & 8 & 2 \\
\hline H-3273 & $\mathbf{M}$ & 45 & farmer & Weonju & $28 /$ Oct $/ 73$ & + & + & m & 7 & 2 \\
\hline H-3373 & $\mathbf{M}$ & 42 & farmer & Yangpyeong & $23 /$ Oct $/ 73$ & + & $H$ & $H$ & 5 & 2 \\
\hline H-4673 & $\mathbf{F}$ & 22 & $\begin{array}{l}\text { house } \\
\text { keeping }\end{array}$ & Koyang & 8/Nov/73 & \pm & H & H & 5 & 2 \\
\hline
\end{tabular}

TABLE VI

Number of Korean small mammals tested for CF antibody

\begin{tabular}{lc}
\hline \multicolumn{1}{c}{ Species } & Number CF-tested \\
\hline Apodemus agrarius & 314 \\
Apodemus speciosus & 1 \\
Mus musculus & 2 \\
Micromys minutus & 1 \\
Rattus norvegicus & 1 \\
Microtus fortis & 16 \\
Eothenomys regulus & 12 \\
Crocidura lasiura & 18 \\
Sorex caecutiens annexus & 1 \\
\hline Total & 366 \\
\hline
\end{tabular}

and a serum from Rattus norvegicus inhibited 8 units of JE antigen at dilutions of $1: 10$ and 1:20. The above sera also showed cross-reactions against other group B arbovirus antigens. Group A arbovirus antigens and the antigen of a Bakau group virus (Ketapang) were not inhibited.

b) CF antibodies: A total of 37 small mammal sera were found either anticomplementary or reacted non-specifically and, therefore, were excluded from the count. Three hundred and sixty-six sera were tested against ASK-1, Congo, LCM, Tacaribe, Pichinde and dengu type 2 antigens. A breakdown by mammal species is given in Table VI. Apodemus agrarius comprised 314 of 366 sera. The only 
positives were: a serum from Apodemus agrarius trapped on 15 November against dengue type 2 at 1:4, and another Apodemus agrarius serum showed a titer of 1:4 against ASK-1 antigen. Fifty-nine of the above 366 sera were further tested against Apoi and Lassa virus antigens. The results were negative.

\section{Discussion}

General impression in the ecological observation of the study area together with the afore-mentioned epidemiological data suggests strongly that there has been no substantial change in the epidemiological feature of KHNN since earlier observations made in 1952 (Gould and Craig, 1954) and 1954 (Dodge et al., 1956). The apparent involvement of a number of southern provinces, higher incidence in males than females, and lowering trend of spring epidemic peaks, in recent years seem to be of relative importance when compared with more fundamental characteristics of KHNN outbreaks such as: (a) the absence of disease among children and in urban areas, (b) bimodal outbreak peaks, and (c) consistently high incidence in certain counties, which remain unaltered for 25 years.

Apodemus agrarius which comprised the overwhelming majority of specimens in the present studies is by far the most abundant species of small mammal in the classic endemic area of KHNN (Traub et al., 1954; Walton and Hong, unpublished data). The latter investigators have confirmed the bimodal reproductive periodicity among these Korean rodents, a spring peak followed by a midsummer decline with another peak in late summer to early fall. As most of the Apodemus agrarius captured during the survey period were probably between 2 and 6 months of age (Walton and Hong, unpublished data), the significant increase in the size of the Apodemus agrarius population in late spring and mid fall appear temporarily associated with the bimodal peaks of KHNN incidence.

As regards arthropod vectors, Traub et al. (1954) suggested that Trombicula pallida (Leptotrombidium pallidum) was the species most closely fitted the seasonal incidence of KHNN. Apparently, a large number of mites as well as chigger pools were tested for virus during the $1950 \mathrm{~s}$ without positive results (unpublished). Negative results ensued from another attempt made by Kim and Shin (1963). The results of the present studies on 131 mite pools further decrease the likelihood that mites play a vector or carrier role for the KHNN etiological agent.

During 1965, 45 pools of animal excreta and 276 patient specimens such as blood, urine, feces and post-mortem tissue were tested for virus in six cell lines by the 406th Medical Laboratory (US Army Medical Command Japan, 1965). No agents were recovered. 
Recently, Lee $(1972,1973)$ employing three cell lines attempted virus isolation from the sera of 115 patients, four specimens of kidney biopsy, suspension or tissue specimens of spleen and lymphnodes from 408 rodents. Two viral agents were isolated from two Apodemus agrarius. They failed to be neutralized, however, by the sera of KHNN patients at convalescence.

In view of the known reservoir role played by genus Mus (LCM, Junin) Calomys (Machupo), and Mastomys (Lassa) in the natural transmission cycle of arenaviruses, it was considered necessary to ascertain whether or not Apodemus agrarius, the representative genus of the family Muridae in the endemic area, was infected with some arenavirus. The major rationale of the present studies was that in Korean small mammals: (a) virus shedding in urine had been examined only to a limited extent; and, (b) a search for serum antibodies against arenaviruses had never been undertaken.

Prior to a conclusion, the limitations of the methods employed herein should be demarcated. It is admitted that only those viruses which are pathogenic to suckling mice could have been detected. Most arenaviruses (Tacaribe, Junin, Machupo, Amapari, Tamiami and Pichinde) are known to kill suckling mice in a high dilution; however, exceptions such as LCM and Lassa viruses also exist. It is also noted that CF is the method of choice to pick up cross-reacting antibodies of known members of the arenaviruses; nevertheless, the negative results in the CF tests may not necessarily preclude a new arenavirus. The failure in present as well as previous studies indicates that future search for a causative virus, if undertaken, should employ more sophisticated methods.

Despite the above limitation, it seems worthwhile to recall the high prevalence of infected reservoir mammals in arenaviruses. For example, Monath et al. (1974) isolated Lassa virus from 14 out of 82 Mastomys in the endemic area. It is striking that 12 of 14 Mastomys trapped in and around the premises where a case of Lassa fever had occurred were found infected. Should the negative results of the present studies relative to almost 100 human cases that were diagnosed in the study area during the period be compared to known infection rates of arenavirus reservoirs of $3-30 \%$, it would appear unlikely that an arenavirus pathogenic in suckling mice or cross-reactive in the CF tests or both was being transmitted among Apodemus agrarius.

\section{REFERENCES}

Buckley, S. M. And Casals, J. (1970): Lassa fever, a new virus disease of man from West Africa. III. Isolation and characterization of the virus. Am. J. Trop. Med. Hyg., 19, 680-691.

Dodge, H. J., Griffin, H. E., Gauld, R. L. ANd Kim, Y. S. (1956): Epidemic haemorrhagic fever in a Korean farm population. Am. J. Trop. Med. Hyg., 63, 38-51.

Gauld, R. L. ANd Craig, J. P. (1954): Epidemiological pattern of localized outbreaks of epidemic hemorrhagic fever. Am. J. Hyg., 59, 32-38.

IsHII, S. (1942): Studies on Song-go fever. Japan. Army Med. J., 335, 1755-1758 (in Japanese). 
Johnson, K. M., Wiebenga, N. H., Mackenzie, R. B., Kuns, M. L., Tauraso, N. M., Shelokov, A., Webe, P. A., Justines, G. AND BeyA, H. K. (1965): Virus isolations from human cases of hemorrhagic fever in Bolivia. Proc. Soc. Exptl. Biol. Med., 118, 113-118.

Kim, M. Y. And Shin, H. K. (1963): An etiological survey of the mites as a possible vector of epidemic haemorrhagic fever. Army Med. J., 9, 64.

Krm, K. H., Antal, G. M. AND Shin, H. K. (1974): Epidemiological studies on haemorrhagic nephrosonephritis in the Republic of Korea. Korean J. Virol., 4, 29-39.

LEE, H. W. (1972): Korean haemorrhagic fever. Annual report FE-464-2, DA-CRD-AFE-S92. 544-71-G167-1972.

LEE, H. W. (1973): Korean haemorrhagic fever. Annual report FE-464-4, DA-CRD-AFE-S92544-71-G167-1973.

Monath, T. P., Newhouse, V. F., Kemp, G. E., Setzer, H. W. and Cacciapouti, A. (1974): Lassa virus isolation from Mastomys natalensis rodents during an epidemic in Sierra Leone. Science, $185,263-265$.

Parodi, A. S., Greenway, D. J., Rugiero, H. R., Greenway, D. J., Mettler, N., Martinez, A., BoXaca, M. AND BARrera, J. M. DE LA (1958): Sobre la etiologia del brote epidemico de Junin. Dia Medico, 30, 2300-2302 (in Spanish).

Traub, R., Hertig, M., Lawrence, W. H. and Harris, T. T. (1954): Potential vectors and reservoirs of hemorrhagic fever in Korea. Am. J. Hyg., 59, 291-305.

US Army Medical Command Japan (1965): Professional report 406th Medical Laboratory, p. 242-246. 